\title{
UNNES \\ The Enhancement of Senior High School Students' Analytical Thinking Skills in Learning Excretory System Material with Quantum Learning Model
}

\author{
Eka Aprilia Mardiansyah ${ }^{1 凶}$, Sigit Saptono ${ }^{1}$, Ning Setiawati $^{2}$
}

Departement of Biology, FMIPA, Universitas Negeri Semarang, Indonesia

\begin{tabular}{l} 
Info Articles \\
\hline History Articles: \\
Received: January 2019 \\
Accepted : March 2019 \\
Published: April 2019 \\
\hline Keywords: \\
analytical thinking skills, \\
quantum learning, excretory \\
system
\end{tabular}

\begin{abstract}
High-level thinking skills are incredibly required to face the challenges in the 21st-century era. One of it skill is to think analytically or people commonly call it analytical thinking. Analytical thinking skills can be trained to the students with an effective learning model. This study aims to describe the enhancement of the analytical thinking skills of high school students on the learning of excretory system materials with quantum learning model. The subject in this study students grade XI in SMA Negeri 1 Boja, and MA Al-Asror which each of 2 classes of treatment. This research design is a quasi-experimental, with non-equivalent design pretest-posttest Documentation, tests, questionnaires, and interviews are used as data collection techniques. The enhancement of students' analytical thinking skills on learning of excretory system materials with quantum learning model as primary data was analyzed with $\mathrm{N}$-gain. The result of data analysis showed an increase of average analytical thinking skills of $\mathrm{N}$-gain in both treatment class of MA Al-Asror of 0,53 with the medium category and in both treatment class of SMA Negeri 1 Boja equal to 0,79 with the high category. The secondary data result the average percentage of student activity in MA Al-Asror 79\% and SMA Negeri 1 Boja $81,1 \%$, both percentages are classified into a nice category. The analysis students questionnaire assessment in MA Al-Asror is $81 \%$ with effective category and SMA Negeri 1 Boja is $82 \%$ with the very effective category. The result of the analysis of teacher questionnaire assessment in MA Al-Asror is $75 \%$ with effective category and SMA Negeri 1 Boja is 97,5\% with the very effective category. Interviews with students and teachers being presented by descriptive. Analytical thinking skills covering of identifying, distinguishing, and linking cause and effect is increased in learning of excretory system material with quantum learning model.
\end{abstract}




\section{INTRODUCTION}

Education is a crucial aspect to support the human life. In the 21st century, people require an important competence that are the ability to think critically and solve problems, collaborate, communicate, create, and innovation (Roekel, 2002). Those capabilities should be implemented by a scientific approach to face the challenge of the 21st century (Beers, 2012). According to Sufairoh (2016), scientific approach is a learning process designed to learners can actively construct the concept, law or principle through stages including observation (to identify or find problems), formulating the problem, proposing or formulating hypotheses, collecting data using various techniques, analyzing data, drawing conclusions and communicating a concept as well as principle of law or "found." A scientific approach is intended to provide insight to the students to understand that different material/information can be originated from anywhere, at any time, not only obtained direct information from teachers.

The current system of education in Indonesia is implementing a curriculum of 2013. 2013 curriculum has undergone revision. One part of the curriculum revised 2013 is the standard process. The standard process is an innovative standard should be implemented. One of the learning models that can be used in the process of learning is quantum learning. Quantum Learning model is effective and fun learning, so students can do well the lesson and activities that can affect the achievement of desired competencies. The syntax contained in quantum learning is TANDUR. TANDUR syntax is short for "grow, natural, named, demonstrated, repeat, and celebrate the learning design framework is quantum learning (De Porter, 2003).

Based on an initial study conducted in SMA Negeri 1 Boja, Kendal, SMA Negeri 1

Slawi, and MA Al-Asror that students score in the excretion system reach an average value of 75. This looks good, but based on discussion with teachers of biology can be known analytical thinking ability of students is still low. This is evidenced by the existence of monotonous learning, including less-active students in asking and answering questions from teacher especially on the material system for excretion. Fun learning takes students to increase the liveliness, so students have a greater chance to hone the ability to think analytically. In addition, the material requires excretion system supporting media to be able to represent material excretion system to the students. The media is created to facilitate the students so that students feel more comfortable. During this time the teacher use powerpoint media visualization of material that isn't clear enough because of the slide switch without seeing the students' opportunity to understand it. According to Caroline et al (2013), analytical thinking is very important in learning biology due to the demands of students to be able to solve the problems that are encountered in daily life. It is also supported by Areesophonpichet (2013), the ability to think analytically became one of the important capabilities because it supports higher-order thinking. Analytical thinking capabilities included with the HOTS (High Order Thinking Skills) which is one of the demands of the Curriculum 2013. Based on the results of the study literature, some analytical ability that student i.e. ability to identify system idea idea excretion (Moore 2001, Pardjono 2009, Montaku and 2012), the ability to distinguish (Anderson and Krathwohl, 2001 Pardjono 2009, 2015, and Dostal Laksono 2017), and the causal analysis capabilities (Ross (Maulana 2014), Anderson and Krathworl 2001, and Moore 2001).

Learning media is required to facilitate the delivery of the material and the concepts to students in order to be able to master it. In education, there is a wide range of media. According to Saptono (2009), picture cards can be utilized in developing learning biology in fun. Learning will be more effective if the objects and events that become media teaching can be visualized or 
realistically resemble the actual circumstances. One form of media that can represent the structure of a network of constituent organs of the excretory system, namely media Edu-pop (Education Cards and pop-up) which essentially from the pop-up card (Card). The pop-up is one medium that can represent something in 3D form (Dzuanda, 2011). According to Bluemel (2012), the pop-up has the advantage to bridge the connection between real-life situations, to develop critical thinking and creative ability for students through the images that can be captured in its meaning. In addition, a pop-up can provide a question (Edu Card) to further strengthen in the learning fun with the media pop-up. Students can interact directly with the 3D image media so that the attainment of competencies learning, one analytical thinking ability can be achieved.

Analytical ability in this study is that the student can define the idea of content material excretion system, students can distinguish the constituent organs of the excretory system network, and students can connect the cause and effect of a problem/ disorders of the excretory system. The purpose of this study was to describe the application of the model of quantum learning-assisted media edu-pop on the excretion system material and describes the analytical thinking ability of students on the application of the model of quantum learning edu-media-aided pop.

\section{RESEARCH METHOD}

This research has been carried out in Al-MA Asror and SMA Negeri 1 Boja in April 2018. The populations all students of Class XI MA Al-Asror and Class XI SMA Negeri 1 Boja. The sample in this research is students of Class XI and XI IPA IPA 12 MA Al-Asror and Class XI and XI 45 MIPA SMA Negeri 1 Boja as a class treatment taken with purposive sampling technique. Structure design of this research are as follows:

Table 1 Design research on Non-Equivalent Pretest-Posttest Design

\begin{tabular}{cccc}
\hline Group & Pretest & Treatment & Posttest \\
\hline Experiment Group & $\mathrm{O}_{1}, \mathrm{O}_{3}$ & $\mathrm{X}$ & $\mathrm{O}_{2}, \mathrm{O}_{4}$ \\
\hline
\end{tabular}

Note:

$\mathrm{X}$ : treatment using models of learning; O1, O3: pretest values before performing the activity of learning using learning model of Quantum Learning in class treatment; O2, O4: posttest values after performing activities of learning using learning model of Quantum Learning in class treatment.

There are two types of data in this study which are primary data and secondary data. Primary data will show the enhancement analytical thinking ability of students that analyzed from $\mathrm{N}$-gain pretest and posttest values. Secondary data is in the form of activity of the student that the student's response in the form of questionnaires and interviews. Engineering data retrieval with documentation, tests, questionnaires, and interviews.

\section{RESULTS AND DISCUSSION}

The application of the Quantum Learning Model to the material of the excretion system. Learning that use the model of Quantum Learning can improve the analytical capabilities of the SMA students material Excretion System. The learning process of applying syntax TANDUR (grow, natural, named, demonstrated, repeat, and celebrate). The first syntax, 
IE "Grow", investigators infuse flavor AMBAK ("Apa Manfaatnya Bagiku?") against the students in the class. The cultivation of the sense of AMBAK by providing questions that stimulate students to think, and gravitated towards the learning material this Excretion System. "Natural", researchers give the opportunity to students to learn (experienced) learning material Excretion System by utilizing the existing learning resources in groups. The third syntax of "Name", the researchers invited the students to classify the parts of the media of the Edu-Pop and give a name to every part of it (the name). The syntax of the fourth, namely "Demonstrated". The fifth syntax i.e. Repeat ", researchers give a repeat against learning material excretion via the medium of Edu-Pop that is in the form of cards read by a group of publishers against other groups quickly and precisely. Analytical thinking ability is getting drilled against the students. The last syntax is "Celebrate", researchers give a reward (awards/prizes) for all students who have been learning to use the Quantum Learning model. The reward is given in the form of a sticker "zeal" that can keep the consistency of the spirit of the students, as well as gifts. The faces of the students getting a smile when they get the top award the struggle they had to accomplish, namely to train students ' analytical thinking ability.

Table $2 \mathrm{~N}$-gain Data Results thinking ability analysis of MA Al-Asror

\begin{tabular}{lcccccc}
\hline \multicolumn{1}{c}{ Data } & \multicolumn{2}{c}{ Eksperimen XI IPA 1 } & \multirow{2}{*}{ N-gain } & \multicolumn{2}{c}{ Eksperimen XI IPA 2 } & \multirow{2}{*}{ Pretest } \\
& Pretest & Posttest & Posttest & \\
\hline $\begin{array}{l}\text { Score lowest } \\
\begin{array}{l}\text { Score } \\
\text { highest }\end{array}\end{array}$ & 40 & 65 & & 15 & 50 & \\
Average & 75 & 90 & 0,59 & 90 & 95 & 0,46 \\
\hline
\end{tabular}

Based on Table 4.2. The results of N-gain second class in MA Al-Asror has adequate capacity to think the analysis is being in class XI IPA 1 was 0.59 , and Class XI IPA 2 is 0.46 . Obtained percentage average N-gain MA Al-Asror i.e. 0.53, included in the criteria being. Table 4.3 Results N-gain Data the results of the analysis of the thinking ability of SMAN 1 and circus.

Table $3 \mathrm{~N}$-gain Data the results of the analysis of the thinking ability of SMAN 1 Boja

\begin{tabular}{lcccccc}
\hline \multirow{1}{*}{ Data } & \multicolumn{2}{c}{ Treatment } & \multicolumn{4}{c}{ Treatment } \\
& \multicolumn{2}{c}{ XI MIPA 4 } & N-gain & \multicolumn{2}{c}{ XI MIPA 5 } & N-gain \\
& Pretest & Posttest & & Pretest & Posttest & \\
\hline Nilai & 55 & 75 & & 25 & 75 & \\
tertinggi & 85 & 100 & 0,77 & 75 & 100 & 0,81 (tinggi) \\
Rata-rata & 65,17 & 92,07 & (tinggi) & & & \\
\hline
\end{tabular}

Based on Table 3 Results N-gain both classes at SMA Negeri 1 Boja have adequate capacity to think the High analysis in class XI SCIENCES 4 is 0.77 , and Class XI SCIENCES 4 is 0.81 . Obtained percentage average $\mathrm{N}$-gain SMA Negeri 1 i.e. 0.79 , And included in the criteria. In addition to the results of $\mathrm{N}$-gain the ability to think the analysis presented in General, also presented the results of the analysis of $\mathrm{N}$-gain every indicator of ability to think the analysis in this study. An indicator of the ability of thinking in this research analysis there is 3 i.e. the ability to identify, distinguish, and linking cause and effect related to the material tissue system of BioProcess systems, excretion excretion excretion of distractions, and systems. It is presented in Table 4. 
Table $4 \mathrm{~N}$-gain every indicator analysis of thinking ability of students in the MA Al-Asror and SMA Negeri 1 Boja

\begin{tabular}{llcccc}
\hline & \multicolumn{2}{c}{$\begin{array}{c}\text { Analytical thinking } \\
\text { ability }\end{array}$} & \multicolumn{2}{c}{ MA Al-Asror } & \multicolumn{2}{c}{ SMA Negeri 1 Boja } \\
& XI IPA 1 & XI IPA 2 & XI MIPA 4 & XI MIPA 5 \\
\hline Pretest & Identify & 50,2 & 61,6 & 56,4 & 73,3 \\
& Distinguish & 57 & 40,8 & 49,1 & 53,3 \\
& Connect & 68 & 68,6 & 54,1 & 78,7 \\
\hline Posttest & Identify & 97,7 & 79,7 & 95 & 95 \\
& Distinguish & 93,1 & 73,5 & 82,2 & 85,6 \\
& Connect & 82,1 & 76 & 95,1 & 97 \\
\hline
\end{tabular}

Based on Table $4 \mathrm{~N}$-gain every indicator of the ability of thinking in the analysis of MA Al-Asror and SMA Negeri 1 Boja experience increased. N-gain MA Al-ability to identify indicators for Asror, distinguishing and linking cause and effect is dominant in class XI SCIENCE 1 . The ability to identify increased from 50.2 is 97.7 . The ability to distinguish is raised from 57 became 93.1. The capability of linking cause and effect is increased from 68 to become 82.1 .

The results of $\mathrm{N}$-gain SMA Negeri 1 Boja the indicator for the ability to identifying, distinguishing, and linking cause and effect second class is not too much different. The ability to identify the dominant class of SCIENCES XI 4 i.e. from 56.4 becomes 95 . The ability to distinguish a class of SCIENCES XI 4 of 49.1 be 82.2. The capability of linking cause and effect of Class XI of SCIENCES of 54.1 becomes 95.1 .

In addition to the primary data that have been described from the results of research, secondary data obtained. The observation activities of students at the MA Al-Asror and SMA Negeri 1 Boja carried out by the observer. Each student was given a nametag (students) to facilitate observation observer. Each class is given a different nametag treatment. MA Al-Asror in class XI IPA 1 amounted to 19 students, and Class XI IPA 2 amounted to 21 students and SMA Negeri 1 Boja in class XI and 4th XI SCIENCES SCIENCES 5 respectively amounted to 29 students. Observations observation activity during the learning process taken placed can be seen in tables 5 and 6.

Table 5 Activity Grade XI MA Al-Asror

\begin{tabular}{|c|c|c|c|c|c|c|}
\hline \multirow{2}{*}{ No } & \multirow{2}{*}{ Student activity indicator } & \multicolumn{2}{|c|}{ Skor } & \multicolumn{2}{|c|}{ Skor Max } & \multirow[t]{2}{*}{ Total Persentage (\%) } \\
\hline & & IPA 1 & IPA 2 & \multicolumn{2}{|c|}{ IPA 1 IPA 2} & \\
\hline 1. & $\begin{array}{l}\text { Attention student against } \\
\text { teacher }\end{array}$ & 48 & 54 & 57 & 63 & $85 \%$ \\
\hline 2. & $\begin{array}{l}\text { The Working Group is active } \\
\text { in the discussion }\end{array}$ & 45 & 51 & 57 & 63 & $77 \%$ \\
\hline 3. & $\begin{array}{l}\text { Student behavior when } \\
\text { conducting discussions }\end{array}$ & 42 & 48 & 57 & 63 & $75 \%$ \\
\hline 4. & $\begin{array}{l}\text { Active asked when having } \\
\text { difficulty }\end{array}$ & 45 & 45 & 57 & 63 & $75 \%$ \\
\hline 5. & Complete the tasks in a group & 45 & 51 & 57 & 63 & $80 \%$ \\
\hline 6. & Create conclusion & 48 & 51 & 57 & 63 & $82 \%$ \\
\hline \multicolumn{6}{|c|}{ Average of score percentage (\%) } & $79 \%$ \\
\hline & \multicolumn{5}{|c|}{ Category } & Baik \\
\hline
\end{tabular}


The following Activity Grade XI SMA Negeri 1 Boja presented in table 6.

Table 6 Activity students in SMA Negeri 1 Boja

\begin{tabular}{|c|c|c|c|c|c|c|}
\hline \multirow{2}{*}{ No } & \multirow{2}{*}{ Student activity indicator } & \multicolumn{2}{|c|}{ Skor } & \multicolumn{2}{|c|}{ Skor Max } & \multirow{2}{*}{$\begin{array}{c}\text { Total } \\
\text { Persentage(\%) }\end{array}$} \\
\hline & & MIPA 4 & MIPA 5 & MIPA 4 & MIPA 5 & \\
\hline 1. & $\begin{array}{l}\text { Attention student against } \\
\text { teacher }\end{array}$ & 72 & 75 & 87 & 87 & $84 \%$ \\
\hline 2. & $\begin{array}{l}\text { The Working Group is active } \\
\text { in the discussion }\end{array}$ & 69 & 72 & 87 & 87 & $81 \%$ \\
\hline 3. & $\begin{array}{l}\text { Student behavior when } \\
\text { conducting discussions }\end{array}$ & 69 & 66 & 87 & 87 & $77 \%$ \\
\hline 4. & $\begin{array}{l}\text { Active asked when having } \\
\text { difficulty }\end{array}$ & 66 & 72 & 87 & 87 & $79 \%$ \\
\hline 5. & Complete the tasks in a group & 75 & 72 & 87 & 87 & $84 \%$ \\
\hline 6. & Create conclusion Averag & $\begin{array}{l}72 \\
\text { Categ }\end{array}$ & $\begin{array}{l}72 \\
\text { rcentage }(9\end{array}$ & 87 & 87 & $\begin{array}{l}82 \% \\
81,1 \% \\
\text { Baik }\end{array}$ \\
\hline
\end{tabular}

Based on tables 5 and 6 Activity students during the learning process at both schools belong to either. Data response learning using the learning model of Quantum Learning with media Edu-Pop on improving the thinking ability analysis of high school student material Excretion System every statement questionnaire presented in table 7.

Table 7 Analysis of the Responses of the students towards the Learning Model of Quantum Learning in MA Al-Asror and SMA Negeri 1 Boja

\begin{tabular}{llcc}
\hline No & \multicolumn{1}{c}{ Argument } & MA Al-Asror (\%) & $\begin{array}{c}\text { SMA Negeri 1 Boja } \\
\text { (\%) }\end{array}$ \\
\hline 1. $\quad \begin{array}{l}\text { I interest in the learning fun with the media } \\
\text { has done the Edu-Pop on the material system } \\
\text { of excretion }\end{array}$ & $84 \%$ & $84 \%$ \\
2. $\quad \begin{array}{l}\text { A study conducted with Edu-Pop media } \\
\text { make me easy to understand material }\end{array}$ & $82 \%$ & $83 \%$ \\
Excretion System & $78 \%$ & $78 \%$ \\
3. $\begin{array}{l}\text { Learning Activities are undertaken in class } \\
\text { foster interest in learning }\end{array}$ & $78 \%$ & $83 \%$ \\
4. $\begin{array}{l}\text { A study conducted with media Edu-Pop is a } \\
\text { fun learning activity for me }\end{array}$ & $80 \%$ & $82 \%$ \\
5. $\begin{array}{l}\text { A study conducted with media Edu-Pop train } \\
\text { me to be suggested in the analysis }\end{array}$ & $82 \%$ & $89 \%$ \\
ability to think my analysis of learning began \\
to emerge that do fun with media Edu-Pop \\
learning occurs When the upgrade thinking \\
my self-analysis
\end{tabular}


The calculation of the average percentage of student response MA Al-Asror and SMA Negeri 1 Boja amounting to $81 \%$ and $82 \%$ so that the models of Quantum Learning using learning with media Edu-Pop can be said to be effective in improving students ' thinking ability analysis. The response of the students through the interview sheet instrument consists of five related questions the learning process using Quantum Learning model. The results of the analysis that has been done, most students obtained good grades XI IPA 1, class XI IPA 2 MA Al-Asror, and Class XI SCIENCES 4, as well as Class XI SCIENCES 5 SMA Negeri 1 Boja done in a descriptive analysis.

The average teacher in biology MA Al-Asror and SMA Negeri 1 Boja stated that learning is done in the class made students more actively asking or answering questions, as well as better facilitate students in learning the material Excretion System. The analysis of the responses of teachers towards learning Quantum Learning model in MA Al-Asror and SMA Negeri 1 Boja presented in table 8 below.

Table 8 Analysis of the Responses of teachers towards Learning Quantum Learning Model

\begin{tabular}{|c|c|c|c|}
\hline \multirow{2}{*}{ No } & \multirow[t]{2}{*}{ Aspect } & \multicolumn{2}{|c|}{ Score } \\
\hline & & $\begin{array}{c}\text { Teacher } \\
1\end{array}$ & $\begin{array}{l}\text { Teacher } \\
\quad 2\end{array}$ \\
\hline 1 & $\begin{array}{l}\text { Students interested in learning models against quantum learning } \\
\text { with media edu-pop on the excretion system material }\end{array}$ & 3 & 4 \\
\hline 2 & $\begin{array}{l}\text { Learning quantum learning model with edu-pop media make } \\
\text { students easily understand the material system of excretion }\end{array}$ & 3 & 4 \\
\hline 3 & $\begin{array}{l}\text { A learning model of quantum learning activities that take place in } \\
\text { the classroom foster learning interest of students }\end{array}$ & 3 & 4 \\
\hline 4 & $\begin{array}{l}\text { A learning model of quantum learning with media edu-pop is a fun } \\
\text { learning activities for students }\end{array}$ & 3 & 4 \\
\hline 5 & $\begin{array}{l}\text { quantum learning moel with edu-pop can exercise students to } \\
\text { argument analytical thinking }\end{array}$ & 3 & 4 \\
\hline 6 & $\begin{array}{l}\text { Analysis capabilities of students began to appear when applying the } \\
\text { learning model of quantum learning with media edu-pop }\end{array}$ & 3 & 4 \\
\hline 7 & Learning occurs when increased analysis capabilities to students & 3 & 4 \\
\hline 8 & $\begin{array}{l}\text { Students become motivated to do the effort of maintaining health } \\
\text { system excretion }\end{array}$ & 3 & 3 \\
\hline 9 & $\begin{array}{l}\text { A learning model of quantum learning with the media edu-pop } \\
\text { material excretion system to make students comfortable and active } \\
\text { in learning }\end{array}$ & 3 & 4 \\
\hline \multirow[t]{4}{*}{10} & $\begin{array}{l}\text { A learning model of quantum learning with media edu-pop material } \\
\text { excretion systems are effective at improving analysis capabilities of } \\
\text { students }\end{array}$ & 3 & 4 \\
\hline & Total Score & 30 & 39 \\
\hline & Percentage Score & $75 \%$ & $97,5 \%$ \\
\hline & Criteria & Effective & $\begin{array}{c}\text { Very } \\
\text { effective }\end{array}$ \\
\hline
\end{tabular}

Quantum Learning model in this research is applied by using the media. Edu-Pop media are used to attract the attention of students and support in learning. This is in accordance with the research Nadifah (2014), pop-up media can be an interesting learning media so as to enhance students ' interest in learning. The syntax of "Grow", fostering the interest of students, and students are able to answer the question analysis from teachers. The syntax of "natural", utilizing the experience that has students do to learn material Excretion System. The syntax of "Name", students are able to name/differentiate each section later material Excretion System. 
The syntax of "Demonstrated", students communicate the material System Excretion, and active students ask/respond to material with an indicator identifying, distinguishing, and linking cause and effect material System Excretion. The syntax of the "Repeat", students return to repeat the material system of indicators with the excretion of identifying, distinguishing, and linking cause and effect through a question and answer system competitively. The syntax of "Celebrate", the students get an award (reward) for achievement during learning to keep the interest of students in learning the material Excretion System.

Aspects of the learning process that goes with implementing models of Quantum Learning, one of which is student behavior when conducting a discussion category results, obtained a score of 3 (fringe ideas, ask questions, and be able to answer the question) i.e. $75 \%$ MA Al-Asror and 77\% of SMA Negeri 1 Boja circus. The remaining percentage namely MA AL Asror 25\% and 23\% SMA Negeri 1 less can be stated an idea, asking questions, and answering questions. Factors that affect the lack of the ability to score 3 of this variety, one of them caught his less some students towards the learning that takes place. When learning took place, sometimes there were some students who less attention the lesson since the discussion itself. Based on Table 4.7 related the questionnaire responses, students gained an average percentage of $81 \%$ of the students of Al-MA Asror stated learning with Quantum Learning models qualifies as effective. The average percentage of 82\% SMA Negeri 1 Boja any stated learning with Quantum Learning models qualifies as very effective. This is evidenced by the activities of the students become more active to ask, answer questions, and learn the material model using Excretion System Quantum Learning with media Edu-Pop. The response of MA Al- Asror biology teacher to the implementation of learning with the Quantum Learning model is $75 \%$, included in the effective criteria. The response of biology teacher SMA Negeri 1 Boja against the implementation learning with Quantum Learning model that is $97.5 \%$, are included in the criteria is very effective. There is a significant difference in responses in the MA Al-Asror and SMA Negeri 1 Boja, this is due to the perception of each teacher who influenced from the liveliness of the students, the learning interest of students, and the results increased analysis capabilities in each the school. Both teachers stated that learning with a model of Quantum Learning makes the students more active in the learning process, understanding the material support System assisted media faster excretion of Edu-Pop is used so that it can enhance the ability analysis of the thinking of students.

\section{CONCLUSION}

The implementation of the model of Quantum Learning with syntax TANDUR (Grow, natural, Namai, Demonstrated, repeat, and Celebrate) Edu-media-aided Pop enhanced students to think analytically including identifying, distinguishing, and linking cause and effect. The enhancement of the ability of thinking in the analysis of MA Al-Asror is classified as medium, and SMA Negeri 1 Boja is classified as high.

\section{REFERENCES}

Anderson, L.W., and Krathwohl, D. R. (2001). Taxonomy for learning, teaching, and assessing. A revision of Bloom's taxonomy of education objectives. Theory Into Practice Journal. Vol 41 (4): 212-218. 
Areesophonpichet, S. 2013. A development of analytical thinking skills of graduate students by using concept mapping. Prosiding The Asian Conference on Education. International Academic Forum. Osaka, Jepang. Hlm 1-15.

Beers, S.Z. (2012). 21t-century skills: Preparing students for their future. Tersedia di www.mheonline.com/mhmymath/pdf/21st_century_skills.pdf. [diakses 16-1-2018].

Bluemel, N.L dan Rhonda, H.T. 2012. Ebook: Pop-Up Books A Guide For Teachers and Librarians. California: ABC-CLJO, LLC. Tersedia di https://books.google.co.id/books?id=vlJeUBr8aU8C\&pg=PA14\&dq=pop-, [diakses 16-122017].

De Porter, B. 2003. Quantum Teaching : Mempraktekkan Quantum Learning di Ruang-Ruang Kelas. Bandung : Kaifa.

Dostal, J. 2015. Theory of Problem Solving. Procedia Social and Behavioral Science. 174:2798-2805.

Dzuanda .2011. Design Pop-up Child Book Puppet Figure Series? Gatotkaca?. Jurnal Library ITS Undergraduate. Tersedia di http://library.its.undergraduate.ac.id [diakses 16-12-2017].

Laksono, E.W, et al. 2017. Instrumen Penilaian Kemampuan Berpikir Analitis dan Keterampilan Proses Sains Kimia. Jurnal Kependidikan. Vol 1 (1): 100-110.

Maulana. 2014. Pemanfaatan Tayangan Film untuk Meningkatkan Kemampuan Berpikir Analisis Siswa dalam Pembelajaran IPS. Universitas Pendidikan Indonesia.

Montaku, et al. 2012. The Model of Analytical Thinking Skill Training Process. Research Journal of Applied Sciences. Vol 7(1): 17-20.

Moore, D. T et al. 2001. Intelligence Analysis: Does NSA Have What it Takes." Reprint. Cryptologic Quarterly Journal. Vol. 20(2): 133.

Pardjono, dan Wardana. 2009. Peningkatan Kemampuan Analisis, Sintesis, dan Evaluasi melalui Pembelajaran Problem Solving. Cakrawala Pendidikan. No.3 Thn. XXVIII

Roekel, D.V. 2002. Preparing 21 $1^{\text {st }}$ Century Students for a Global Society. National Education Assosiation.

Saptono, S. 2009. Strategi Belajar Mengajar Biologi. Semarang: Unnes Press.

Sufairoh. 2016. Pendekatan Saintifik dan Mode Pembelajaran K13. Jurnal Pendidikan Profesional. Vol 5 (3): 116-125.

Utami, Y dkk. 2013. Studi komparasi INSTAD dipadu mind map dengan pembelajaran konvensional terhadap kemampuan berpikir analitis biologi siswa kelas XI IPA SMAN 4 Surakarta. Pendidikan Biologi: FKIP UNS. 